\title{
IDENTIFIKASI PENYEBAB KERUSAKAN BIOLOGIS GAMBAR CADAS GUA PRASEJARAH MAROS, SULAWESI SELATAN
}

\section{IDENTIFICATION ON THE CAUSES OF BIOLOGICAL DETERORIOTATION OF ROCK ART IN MAROS, SOUTH SULAWESI}

\author{
Moh. Habibi', Edy Gunawan ${ }^{2}$, Ariyanti Oetari ${ }^{3}$, dan R. Cecep Eka Permana ${ }^{4}$ \\ Balai Konservasi Borobudur', Balai Pelestarian Cagar Budaya Kalimantan Timur², Departemen \\ Biologi, FMIPA, Universitas Indonesia ${ }^{3}$, Prodi Arkeologi, Fakultas Ilmu Budaya, Universitas \\ Indonesia $^{4}$ \\ habib1.botany@gmail.com
}

\begin{abstract}
ABSTRAK
Penelitian ini bertujuan untuk mengidentifikasi mikroorganisme (kapang dan bakteri) yang terdapat pada gambar cadas dan berpotensi sebagai biodeteriogen gambar cadas. Metode penelitian meliputi pengambilan sampel dan identifikasi molekuler. Identifikasi molekuler mengunakan primer 9F (5'-GAG TTT GAT CIT IGC TCAG-3') dan 1510R (5'-GGT TAC CTT GTT ACG ACTT-3') untuk bakteri, ITS1F (5'-CTT GGT CAT TTA GAG GAA GTAA-3') dan ITS4R (5'TCC TCC GCT TAT TGA TAT GC-3') untuk kapang. Siklus PCR yang digunakan pada penelitian ini sebanyak 35 siklus, meliputi Denaturasi $\left(95^{\circ} \mathrm{C}\right.$ selama 15 detik), annealing, dan elongation $\left(72^{\circ} \mathrm{C}\right.$ selama 10 detik). Berdasarkan hasil identifikasi molekuler di peroleh tiga belas jenis mikroorganisme yang terdiri dari empat jenis Bakteri dan sembilan jenis Kapang.
\end{abstract}

Kata Kunci: Gambar cadas; mikroorganisme; identifikasi molekuler

\begin{abstract}
This study aims to identify microorganisms (molds and bacteria) in rock art and potentially as biodeteriogen in rock art. Research methods include sampling and molecular identification. Molecular identification using primers 9F (5'-GAG TTT GAT CIT IGC TCAG-3') and 1510R (5'GGT TAC CTT GTT ACG ACTT-3') for bacteria, ITS1F (5'-CTT GGT CAT TTA GAG GAA GTAA- 3 ') and ITS4R (5'-TCC TCC GCT TAT TGA TAT T-GC-3') for molds. The PCR cycle used in this study were 35 cycles, including Denaturation $\left(95^{\circ} \mathrm{C}\right.$ for 15 seconds), annealing, and elongation $\left(72^{\circ} \mathrm{C}\right.$ for 10 seconds). Based on molecular identification, thirteen types of microorganisms were obtained consisting of four types of bacteria and nine types of mold
\end{abstract}

Keywords: Rock art; microorganism; molecular identification

\section{LATAR BELAKANG}

Gambar cadas prasejarah merupakan jejak budaya yang bersifat universal karena ditemukan hampir di seluruh dunia, baik di Afrika, Eropa, Asia, maupun Australia. Temuan gambar cadas itu umumnya berupa cap telapak tangan, binatang, manusia, geometris, abstrak, dan sebagainya. Di Indonesia gambar cadas prasejarah terbanyak ditemukan di Sulawesi Selatan, Sulawesi Tenggara, Kalimantan Timur, Maluku, dan Papua Barat (Permana 2008; Permana 2014).

Gambar-gambar yang terdapat pada gua prasejarah memberikan bukti tentang adanya kegiatan hidup manusia di dalam gua pada masa prasejarah. Meskipun bentuk dan fungsi dari gambar cadas masih banyak yang belum jelas, namun gambar-gambar tersebut bukan tanpa makna (Bray 1970). Bukti budaya gambar cadas tersebut menunjukkan tentang keberadaan manusia pendukungnya yang telah menetap di tempat tersebut. Jejak budaya itu juga menandakan bahwa manusia telah memasuki babak baru dengan 
meninggalkan kebiasaan hidup berpindah-pindah (nomaden), dan memasuki tahapan kehidupan menetap pada gua atau ceruk (Soejono dan Leirissa 2009)

Penelitian termutakhir gambar cadas prasejarah di Indonesia dilakukan di Maros (Sulawesi Selatan) tahun 2019 yang menunjukkan bahwa di Situs Bulu Sipong teridentifikasi berasal dari sekitar 44 ribu tahun lalu. Motif gambar cadas itu melukiskan adegan perburuan binatang dan gambaran therianthrope (makhluk setengah manusia dan setengah hewan) tertua di dunia (Aubert dkk 2019). Hasil yang menggembirakan itu merupakan penegasan dari penelitian sebelumnya tahun 2014 telah menyimpulkan bahwa gambar cadas di Maros tertua di dunia. Bukti gambar cadas tertua itu terdapat di Situs Gua Timpuseng berupa motif cap telapak tangan tertua dari gua Timpuseng berasal dari 39.900 tahun, dan gambar babi rusa berasal dari 35.400 tahun (Aubert dkk 2014). Kedua hasil penelitian itu membuktikan bahwa gambar cadas dari Maros lebih tua dibandingkan dengan gua El Castillo (Spanyol) yang selama ini dianggap tertua.

Mengingat rentang waktu yang sangat panjang tersebut, banyak gambar cadas yang rusak dan terancam punah. Padahal menurut Bednarik (2003) gambar cadas dengan lingkungan alamiah gua itu sendiri sudah mencapai titik keseimbangan tertinggi. Hal ini terbukti bahwa gambar cadas tersebut yang sudah beribu bahkan puluhan ribu tahun usianya masih dijumpai dalam keadaan yang masih baik. Adanya gangguan pada batuan umumnya sebagai akibat dari proses alami terutama pelapukan. Proses pelapukan itu disebabkan karena cuaca atau iklim antara musim penghujan dan kemarau, kemudian diikuti dengan pengrusakan secara kimiawi dan/atau biologis (Permana dkk 2019). Selain itu, kerusakan gambar cadas juga banyak disebabkan oleh aktivitas manusia, seperti pemukiman, pertanian, pariwisata, dan industri. Seperti juga di belahan bumi atau wilayah lain, gambar cadas di Maros pun mengalami nasib yang sama, yakni banyak terjadi kerusakan.

Beberapa peneliti telah mengkaji kerusakan gambar cadas di wilayah MarosPangkep Sulawesi Selatan, seperti kerusakan yang disebabkan oleh ganggang (algae) pada situs Gua Petta Kere (Suhartono 2012); kerusakan gambar cadas karena faktor perubahan lingkungan sebagai akibat rusaknya hutan sekitarnya karena pembukaan lahan garapan, dan perluasan pemukiman (Permana 2015); dan kerusakan beberapa faktor sekaligus misalnya pelapukan fisik (retak, pecah, aus), pelapukan biologis (algae, moss, lichen), pelapukan kimia (penggaraman, sementasi), serta faktor alam dan manusia (Mulyadi 2016). Pada kesempatan ini, penyebab kerusakan gambar cadas yang dikaji adalah faktor biologis, khususnya jamur dan bakteri. Selain belum banyak kajian yang berhubungan dengan ini, faktor biologis ini pun merupakan penyebab terbanyak kerusakan gambar cadas. Kajian ini berusaha mengidentifikasi jamur dan bakteri penyebab kerusakan gambar cadas agar dapat dicarikan solusi atau upaya pelestariannya.

\section{METODE}

\section{Lokasi Pengambilan Sampel}

Lokasi pengambilan sampel meliputi Leang Timpuseng, Leang Bulu Sipong, dan Leang Jarie. Alasan pemilihan objek situs: (a) lokasi gua yang sering dikunjungi atau diteliti (Timpuseng dan Jarie), dan yang jarang dikunjungi/diteliti karena baru ditemukan (Bulu Sipong), (d) objek gambar cadas umumnya sudah rusak (Timpuseng dan Jarie) dan ada yang masih bagus (Bulu Sipong), (c) situs telah dilakukan pengambilan sampel dating (Timpuseng, Jarie, dan Bulu Sipong), dan (d) situs dekat pemukiman (Timpuseng dan Jarie), dan dekat industri (Bulu Sipong). Berikut deskripsi lokasi pengambilan sampel. 


\section{Leang Bulu Sipong 4}

Bulu Sipong adalah sebuah bukit yang terletak di wilayah administratif Kampung Tamangesang, Desa Botolempangang, Kecamatan Bontoa, Kabupaten Maros. Gua-gua ini ditemukan pertama kali pada tahun 1982 dan dinamakan Leang Bulu Sipong. Leang Bulu Sipong terletak pada posisi astronomis $04^{\circ} 53^{\prime} 34.6^{\prime \prime}$ LS-1 19 36'40.0” BT dengan ketinggian \pm 88 mdpl. Gua horizontal dengan tipe memanjang ini memiliki mulut gua yang menghadap ke selatan, lebar halaman 3,3 m, tinggi 7,6 m, lebar 6,7 m, dan kedalaman gua 62,9 m. Pada Leang Bulu Sipong terdapat beberapa gambar cadas berbentuk motif tangan (hand stenci) dalam berbagai ukuran, selain itu terdapat gambar yang menggambarkan kegiatan perburuan dengan terdapat motif binatang yaitu 2 babi rusa dan 4 anoa yang digambarkan diburu menggunakan tombak atau tali panjang oleh manusia (antrophomorfik). Salah satu gambar anoa ini berukuran panjang $60 \mathrm{~cm}$ dan lebar $35 \mathrm{~cm}$, digambarkan tampak samping dengan teknik kuas dengan cat warna merah yang menggambarkan garis-garis luar untuk membentuk figur anoa.

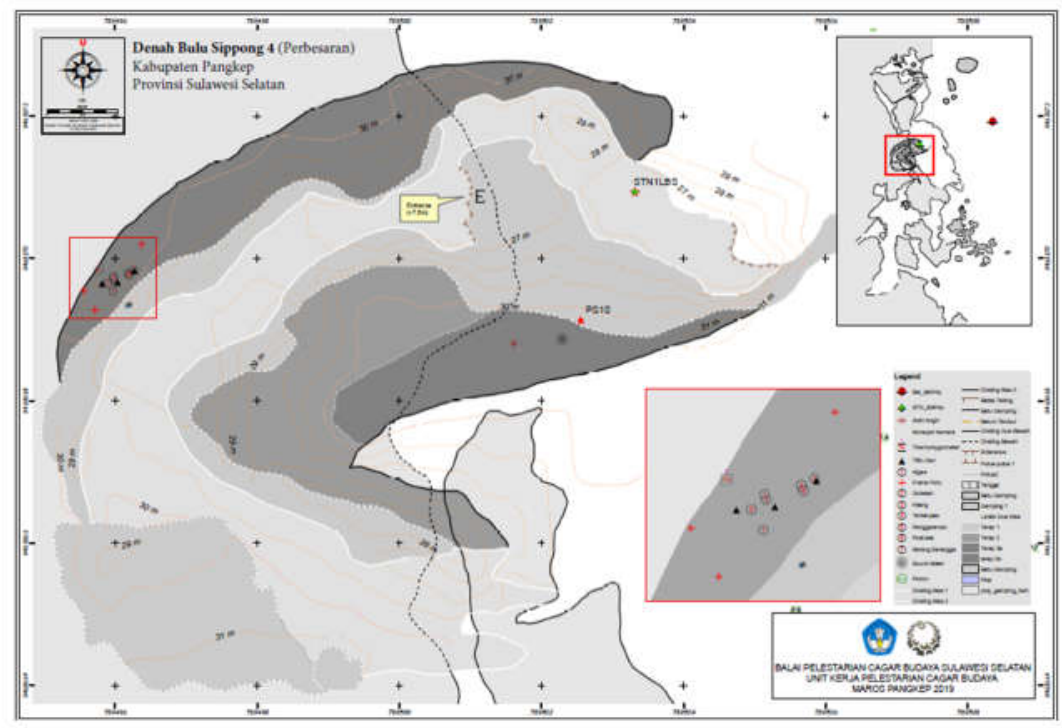

Gambar 1. Denah Leang Bulu Sippong 4 (Sumber: Balai Pelestarian Cagar Budaya Sulawesi Selatan, 2019)

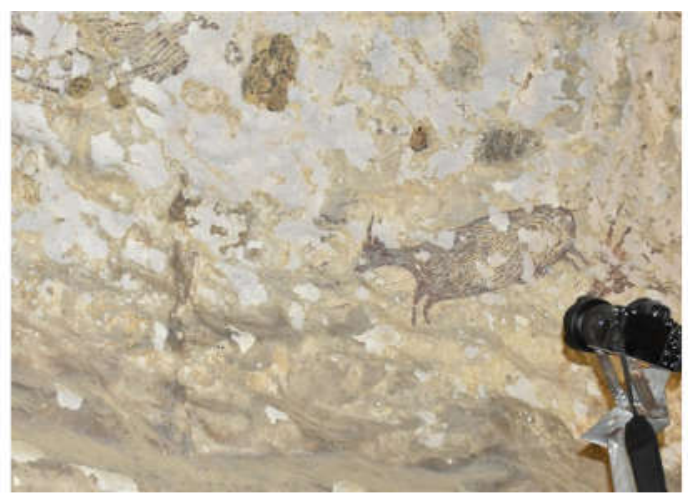

Gambar 2. Gambar cadas Bulu Sipong 3 (Sumber: Penulis, 2019) 


\section{Leang Timpuseng}

Leang Timpuseng terletak sekitar 200 meter dari jalan poros yang menghubungkan Kelurahan Kalabbirang dengan Kelurahan Leang-leang di Kecamatan Bantimurung, Maros. Jaraknya sekitar $40 \mathrm{~km}$ arah timur laut pusat kota Makassar. Gua terletak di kaki bukit karst setinggi setidaknya $100 \mathrm{~m}$, di antara bukit karst dan jalan terbentang sawahsawah warga. Mata air yang berasal dari Leang Timpuseng menjadi sumber pengairan sawah-sawah tersebut, sesuai arti Leang Timpuseng dalam bahasa setempat, yakni "gua mata air". Leang Timpuseng terletak di Kampung Tompobalang, Desa Kalabbirang, Kecamatan Batimurung, Kabupaten Maros. Ceruk ini terletak pada koordinat 04.59'56" LS dan $119^{\circ} 39^{\prime} 36^{\prime}$ "BT dengan ketinggian $\pm 16 \mathrm{~m}$ dpl dan menghadap ke arah tenggara $\left(140^{\circ}\right)$. Mulut ceruk ini berukuran lebar $32 \mathrm{~m}$ dan tinggi $6 \mathrm{~m}$, sedangkan ruang di dalamnya berukuran panjang $9 \mathrm{~m}$, lebar $30 \mathrm{~m}$ dan tinggi $6 \mathrm{~m}$.

Di dalam ceruk ini terdapat gambar tangan serta temuan lain berupa alat batu serpih dan cangkang kerang (Permana 2014: 197). Gambar binatang di gua ini hanya satu yaitu gambar babi. Aubert dkk (2014: 2) melaporkan gambar seekor binatang babi rusa betina yang digambarkan pada langit-langit gua dengan jarak $8 \mathrm{~m}$ dari mulut gua dan tinggi $4 \mathrm{~m}$ dari lantai gua sekarang. Binatang babi rusa betina digambarkan dengan warna merah dengan teknik kuas yang menggambarkan pola garis-garis luar yang membentuk kepala, badan, kaki dan ekor binatang. Garis yang menjadi dasar untuk membentuk figur binatang tersebut digambarkan lebih tebal, yaitu di bagian kepala, badan, ekor, dan kaki binatang. Pada bagian badan binatang digambarkan garis-garis yang membentuk motif bulu binatang tersebut. Di bagian bawahnya digambarkan garis permukaan tanah berwarna merah. Gambar binatang memiliki pertanggalan 35.400 tahun yang lalu menggunakan metode uranium-series, sedangkan gambar tangan yang terletak di sebelah kiri gambar binatang memiliki pertanggalan 39.900 tahun yang lalu. Berdasarkan pertanggalan tersebut, gambar ini termasuk ke dalam penggambaran binatang yang tertua dalam kebudayaan manusia.

Gambar babi tersebut berukuran panjang $80 \mathrm{~cm}$ dan lebar $32 \mathrm{~cm}$. Berdasarkan pengamatan di lapangan dan hasil rekayasa program Dstretch, diduga kuat gambar tersebut menggambarkan binatang babi endemik Sulawesi (Sus celebensis). Penggambaran babi secara naturalis dengan garis-garis bulu pada binatang tersebut terutama di bagian kepala seperti rambut, diduga kuat menggambarkan babi endemik Sulawesi, karena diketahui bahwa babi rusa tidak memiliki bulu.

\section{LeangJarie}

Leang Jarie berada pada titik astronomis 05O 01' 57,1" LS. $119 \mathrm{O} 41$ ' 12,9” BT, sekitar 2,5 km dari Taman Wisata Bantimurung. Leang Jarie berada pada ketinggian 28 meter dpl, 4 meter dari permukaan tanah dengan arah hadap ke selatan. Temperatur suhu rata-rata di dalam gua sekitar 270C dengan kelembaban sekitar 89\%. Sedangkan kelembaban rata-rata dinding gua berkisar antara 17-28\%. Lebar mulut gua sekitar $7 \mathrm{~m}$ dengan tinggi langit-langit mencapai $20 \mathrm{~m}$. Pada beberapa stalagtit dan dinding gua air menetes dari pori batuan. Di langit-langit gua terdapat kelelawar dan walet. Secara geologis, gua ini termasuk dalam gua kekar lembaran. 
Gambar Cadas di Leang Jarie adalah berupa cap tangan yang tersebar di tiga panel. Panel pertama terletak di relung sebelah kanan, terdapat 5 telapak tangan, sedangkan panel kedua terletak di dinding mulut gua sebelah kanan, terdapat 3 cap tangan, dan pada panel ketiga yang letaknya di dinding ujung kanan, terdapat 12 cap tangan. Keunikan cap tangan di leang ini adalah ujung jari-jari yang runcing dan beberapa di antaranya tidak dilengkapi dengan ibu jari, sehingga berbeda dengan kebanyakan cap tangan yang terdapat di gua lainnya.

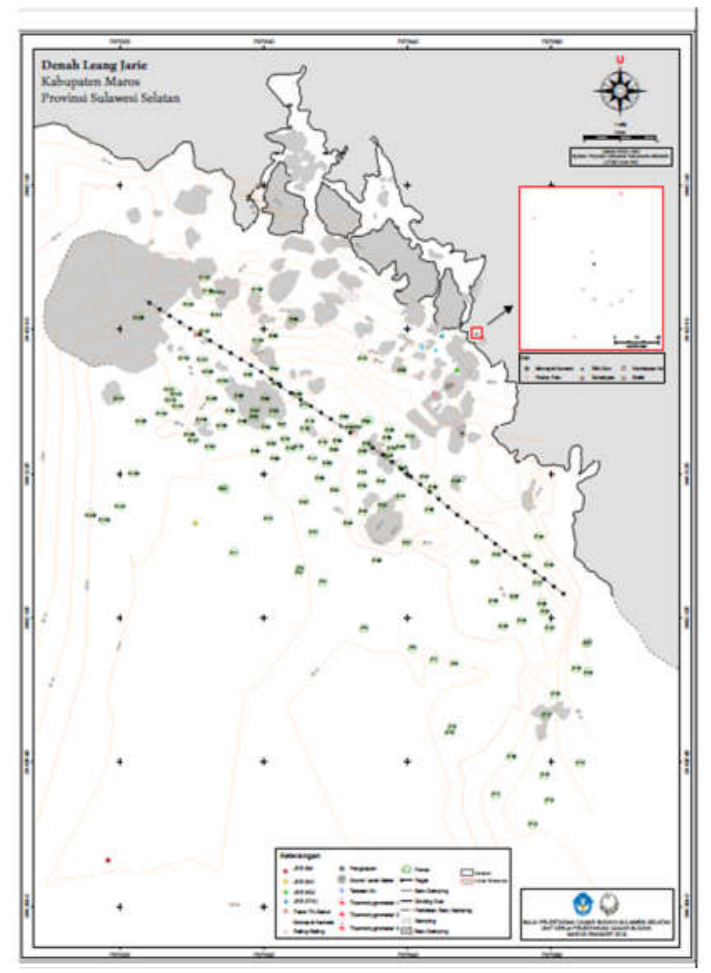

Gambar 3. Denah Leang Jarie

(Sumber: Balai Pelestarian Cagar Budaya Sulawesi Selatan, 2019)

\section{Proses Pengambilan Sampel}

\section{Leang Bulu Sipong}

Pengambilan data dilakukan pada tanggal 21 Juni 2019 pukul 14.30 WITA. Sampel yang diambil adalah Algae hitam. Bagian algae diambil menggunakan scapel steril sebanyak $\_2$ gr kemudian dimasukkan dalam tabung sampel yang steril.

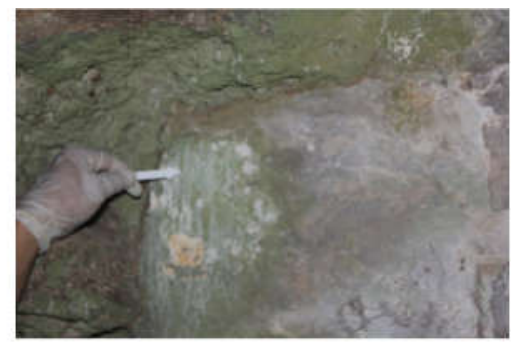

Gambar 4 Pengambilan sampel di Leang Bulu Sipong (Sumber: Penulis, 2019) 


\section{Leang Timpuseng}

Pengambilan data dilakukan pada 22 Juni 2019 pukul 09.55 WITA. Sampel yang diambil adalah Algae hitam. Bagian algae dikupas menggunakan scapel sebanyak $+2 \mathrm{gr}$ kemudian dimasukkan dalam tabung sampel yang steril. Algae hijau, Bagian algae diambil menggunakan scapel steril sebanyak \pm 2 gr kemudian dimasukkan dalam tabung sampel yang steril. Bagian poscorn diambil menggunakan scapel / pisau sebanyak \pm 2 gr kemudian dimasukkan dalam tabung sampel yang steril.
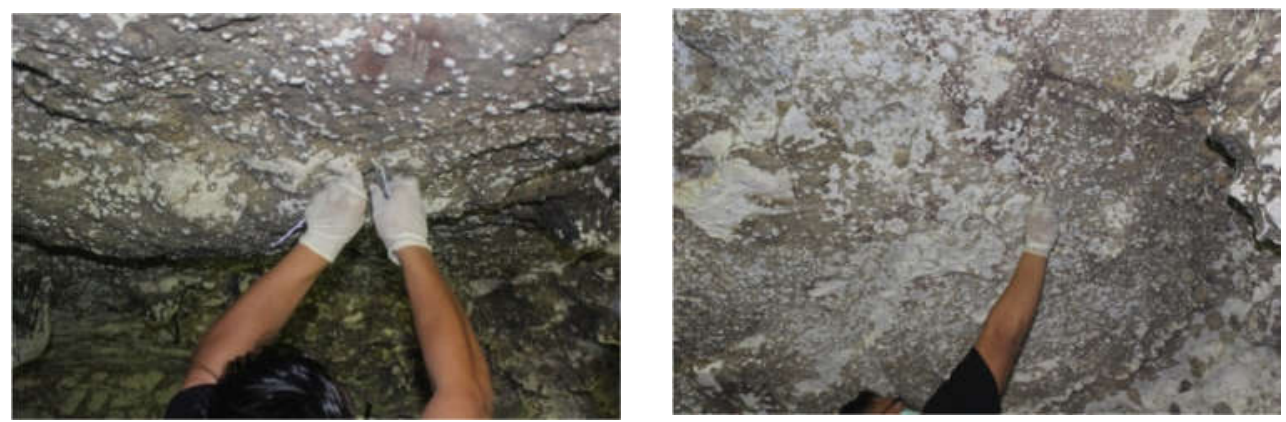

Gambar 5. Pengambilan sampel di Leang Timpuseng

(Sumber: Penulis, 2019)

\section{LeangJarie}

Pengambilan data dilakukan pada 22 Juni 2019 pukul 13.45 WITA. Sampel yang diambil adalah endapan kapur berupa serbuk halus (popcorn) di atas permukaan gambar.

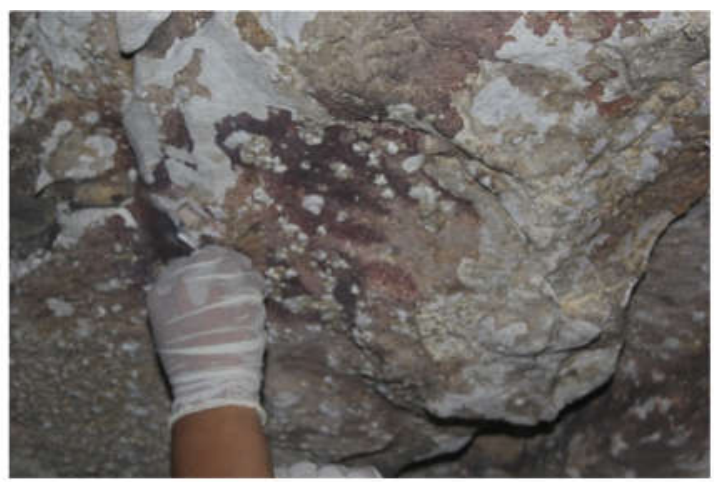

Gambar 6. Pengambilan sampel di Leang Jarie (Sumber: Penulis, 2019)

\section{Identifikasi Molekuler}

Metodologi yang digunakan untuk identifikasi molekular adalah sebagai berikut:

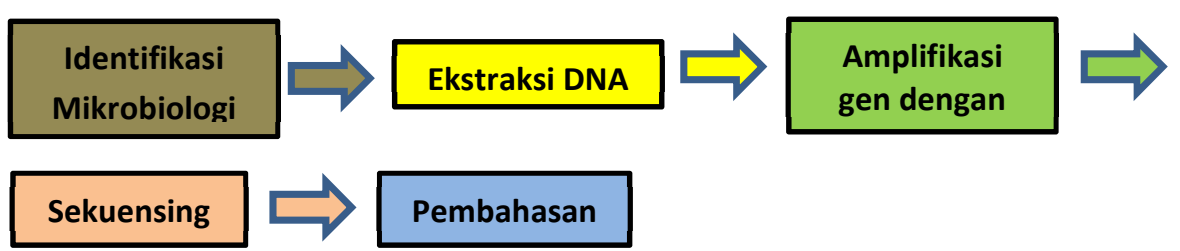

Esktraksi DNA bakteri dilakukan dengan menggunakan Genomic DNA Mini Kit (Geneaid), RNAse A (Geneaid), dan My Taq ${ }^{\mathrm{TM}}$ Red Mix (Bioline). Sedangkan ekstraksi DNA kapang menggunakan Dneasy Plant Mini Kit (Qiagen) dan My Taq Red ${ }^{\mathrm{TM}}$ Mix (Bioline). Amplifikasi gen $16 \mathrm{~S}$ rRNA bakteri menggunakan primer 9F (5'- 
GAGTTTGATCITIGCTCAG-3') dan 1510R (5'-GGTTACCTTGTTACGACTT-3'), sedangkan amplifikasi gen 18S rRNA kapang menggunakan ITS1F (5'CTTGGTCATTTAGAGGAAGTAA-3') dan ITS4R (5'TCCTCCGCTTATTGATATGC-3’). Siklus PCR yang digunakan pada penelitian ini sebanyak 35 siklus, meliputi Denaturasi $\left(95^{\circ} \mathrm{C}\right.$ selama 15 detik), annealing, dan elongation ( $72^{\circ} \mathrm{C}$ selama 10 detik). Produk PCR kemudian di sekuensing oleh First Base, Malaysia. Pencarian homologi bakteri menggunakan program EzBiocloud (https://www.ezbiocloud.net/identify), sedangkan pencarian homologi kapang menggunakan program BLASTN (https://blast.ncbi.nlm.nih.gov/).

\section{HASIL DAN PEMBAHASAN}

\section{Hasil}

Berdasarkan hasil identifikasi molekuler di peroleh empat belas jenis mikroorganisme yang terdiri dari empat jenis Bakteri dan sembilan jenis Kapang. Hasil selengkapnya adalah sebagai berikut.

\section{Leang Timpuseng}

Pada Leang ini, di dapatkan 3 jenis bakteri dan 6 jenis kapang. Ketiga jenis bakteri tersebut adalah Bacillus toyonensis, Bacillus thuringiensis, dan Brevibacillus brevis. Sedangkan ke enam jenis kapang yang berhasil diidentifikasi meliputi Penicillium citrinum, Aspergillus fumigatus, Aspergillus brunneoviolaceus, Trichoderma reesei, Penicillium malachiteum, dan Curvularia beasleyi. Kelompok bakteri yang ditemukan dalam Leang Timpuseng termasuk ke dalam family Bacillaceae. Klasifikasi bakteri family Bacillaceae sebagai berikut:

$\begin{array}{ll}\text { Kingdom } & : \text { Bacteria } \\ \text { Phylum } & \text { : Firmicutes } \\ \text { Class } & : \text { Bacilli } \\ \text { Order } & : \text { Bacillales } \\ \text { Family } & : \text { Bacillaceae }\end{array}$

\begin{tabular}{clc} 
No & \multicolumn{1}{c}{ Tabel 1. Bakteri yang diisolasi dari Leang Timpuseng } \\
Nama & \multicolumn{1}{c}{ Nama } & Similaritas (\%) \\
$\mathbf{1}$ & Bacillus toyonensis & 99,37 \\
$\mathbf{2}$ & Bacillus thuringiensis & 99,79 \\
$\mathbf{3}$ & Brevibacillus brevis & 99,86
\end{tabular}

Bacillus toyonensis

Bakteri berbentuk batang dengan ukuran 3-4 $\mu \mathrm{m}$, membentuk spora, bersifat Gram-positif, motil, dan fakultatif anaerob. Suhu pertumbuhan $10^{\circ}$ hingga $45^{\circ} \mathrm{C}$, suhu pertumbuhan optimum pada $35^{\circ} \mathrm{C}$, pH optimum pada 6,5 ; dan memiliki toleran salinitas hingga $5 \%$ $\mathrm{NaCl}$.

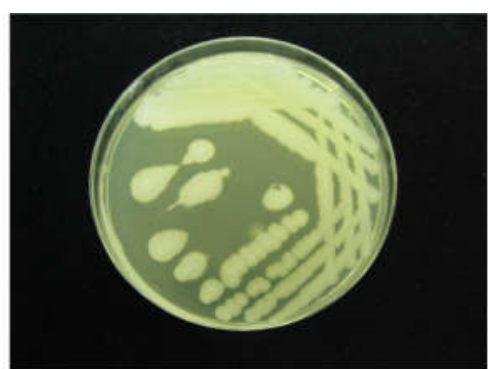

Gambar 7. Isolat bakteri Bacillus toyonensis pada medium NA (Sumber: Penulis, 2019) 


\section{Bacillus thuringiensis}

Bacillus thuringiensis

Bakteri berbentuk batang dengan ukuran $(1,0-1,2) \times(3,0-5,0) \mu \mathrm{m}$, membentuk endospora, bersifat Gram-positif, motil, dan fakultatif anaerob. Endospora menghasilkan endotoksin yang toksik pada serangga dan invertebrata. Suhu pertumbuhan minimum $10^{\circ}$ hingga $15^{\circ} \mathrm{C}$, suhu pertumbuhan maksimum $40-45^{\circ} \mathrm{C}$. Habitat alami species ini di tanah karena endosporanya banyak ditemukan di tanah. Species ini pernah ditemukan di semua benua (continent), termasuk Antartika.

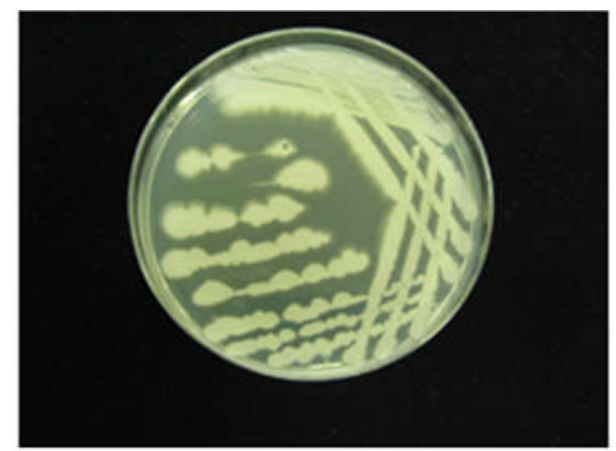

Gambar 8. Isolat bakteri Bacillus thuringiensis pada medium NA

(Sumber: Penulis, 2019)

\section{Brevibacillus brevi}

Bakteri ini berbentuk batang, berukuran $(0,7-0,9) \times 3,0-5,0) \mu \mathrm{m}$, bersifat aerob, Grampositif atau Gram-variabel, motil. Suhu pertumbuhan $30^{\circ} \mathrm{C}$. Sebagian besar tidak tumbuh pada suhu di bawah $20^{\circ} \mathrm{C}$, atau di atas $50^{\circ} \mathrm{C}$. Tidak ada pertumbuhan pada $\mathrm{pH} 5,5$. Species ini seringkali diisolasi dari tanah; pernah ditemukan pada debu udara, susu, rhizosphere, dan kertas.

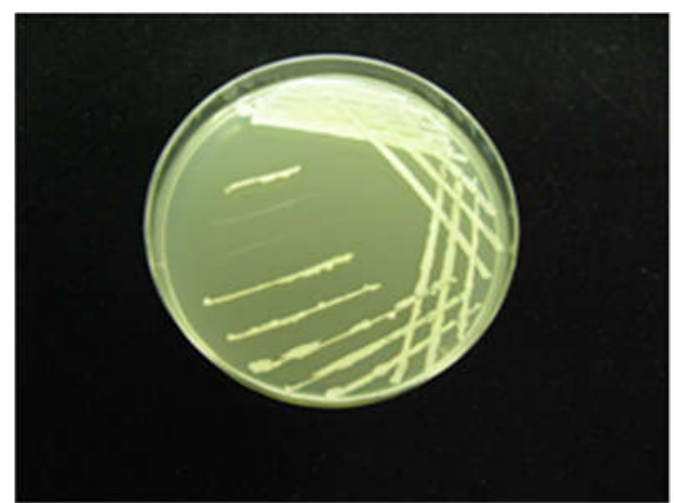

Gambar 9. Isolat bakteri Brevibacillus brevi pada medium NA (Sumber: Penulis, 2019)

Kapang yang berhasil diidentifikasi dari Leang Timpuseng termasuk ke dalam filum Ascomycota. Ciri-ciri filum Ascomycota adalah memiliki askus (kantung) yang mengandung askospora, multiseluler ataupun uniseluler, umumnya hifa bersekat, bercabang, dan berinti banyak, serta memiliki tubuh buah (askokarp).

Tabel 2. Kapang yang diisolasi daru Leang Timpuseng

\begin{tabular}{clc} 
No & \multicolumn{1}{c}{ Nama } & Indeks Similaritas (\%) \\
$\mathbf{1}$ & Penicillium citrinum & 99,82 \\
$\mathbf{2}$ & Aspergillus fumigatus & 99,50 \\
$\mathbf{3}$ & Aspergillus brunneoviolaceus & 99,31
\end{tabular}




$\begin{array}{lll}4 & \text { Trichoderma reesei } & 99,06 \\ \mathbf{5} & \text { Penicillium malachiteum } & 99,47 \\ \mathbf{6} & \text { Curvularia beasleyi } & 99,47\end{array}$

\section{Penicillium citrinum}

Koloni pada Czapek agar berwarna biru hijau. Sebalik koloni berwarna kuning hingga oranye. Koloni memiliki conidiophore, metulae, phialide, dan conidia. Conidia berbentuk bulat atau semi bulat, tidak berwarna. Spesies ini menghasilkan mikotoksin yaitu citrinin. Habitat species ini adalah pangan, dan lingkungan dalam ruangan. Species ini memiliki persebaran luas, dan umum ditemukan di tropik pada sereal, bumbu.

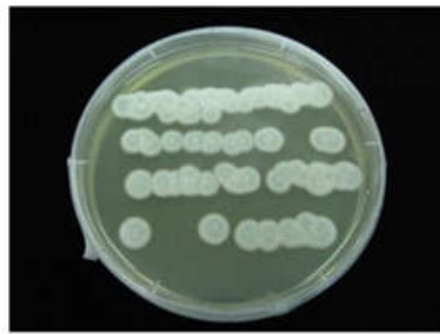

Gambar 10. Isolat kapang Penicillium citrinum pada medium Potatoes Dextrose Agar (PDA) (Sumber: Penulis, 2019)

\section{Aspergillus fumigatus}

Koloni pada Czapek agar berwarna hijau gelap. Koloni memiliki conidiophore, phialide, vesicle berbentuk clavate, conidia berbentuk bulat atau semi bulat. Conidial head memiliki tipe columnar. Spesies ini menghasilkan mikotoksin yaitu gliotoxin, verrucologen, fumitremorgin $A$ dan $B$, dan fumitoxin. Habitat spesies ini pada pangan dan lingkungan dalam ruangan. Species ini umum ditemukan pada sereal, sampah, debu ruangan, kompos. Spesies ini dapat tumbuh hingga suhu $55^{\circ} \mathrm{C}$.
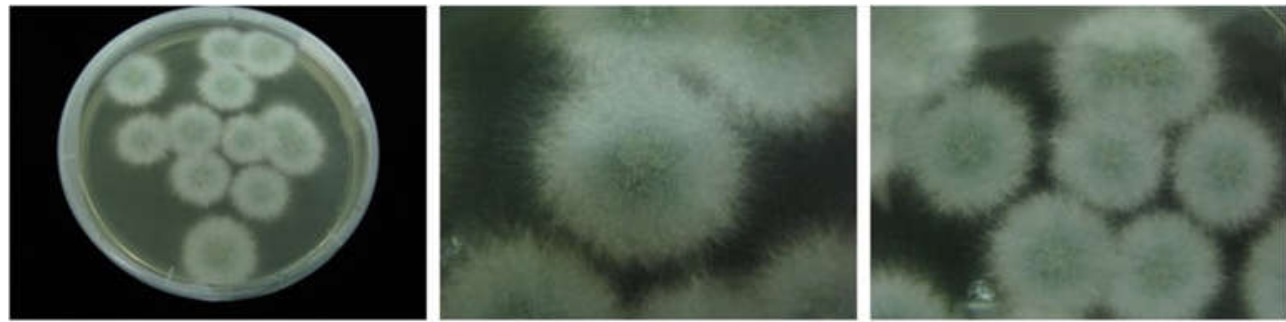

Gambar 12. Isolat kapang Aspergillus fumigatus pada medium Potatoes Dextrose Agar (PDA) (Sumber: Penulis, 2019)

\section{Aspergillus brunneoviolaceus}

Species ini termasuk ke dalam kelompok uniseriate black aspergilli. Koloni tumbuh pada suhu $35^{\circ}$ dan $37^{\circ} \mathrm{C}$ pada medium CYA. Koloni memiliki stipe, phialide, vesicle, conidia bulat hingga elips, berwarna cokelat hingga hampir hitam. Conidial head berwarna cokelat, cokelat gelap hingga hampir hitam, uniseriate. Spesies ini pernah diisolasi dari udara di dalam ruangan 

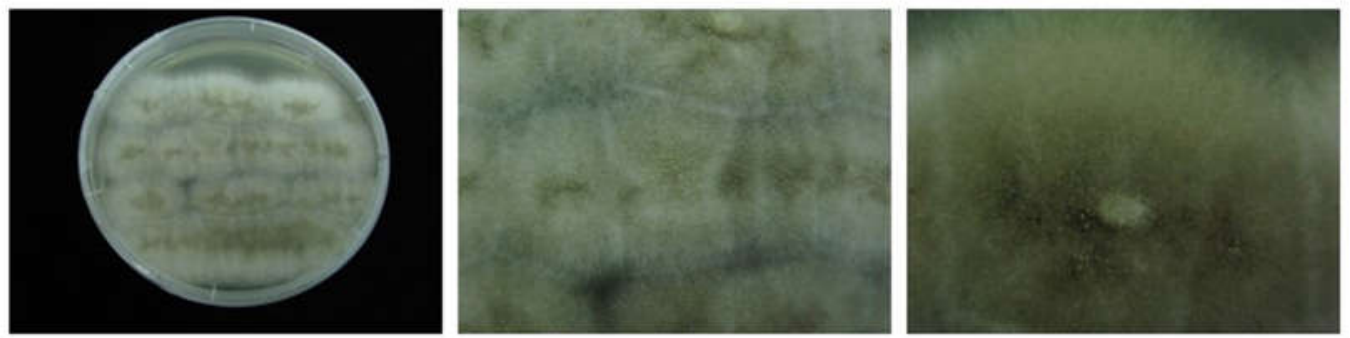

Gambar 13. Isolat kapang Aspergillus brunneoviolaceus pada medium Potatoes Dextrose Agar (PDA)

(Sumber: Penulis, 2019)

\section{Trichoderma reesei}

Koloni berwarna kuning-hijau. Koloni memiliki conidiophore, phialide. Conidia berbentuk elips, dan berwarna hijau pucat. Spesies dari Trichoderma umum ditemukan pada tumbuhan yang membusuk, rhizophere, dan pernah diisolasi dari kecoa, kerang laut, pencernaan rayap.
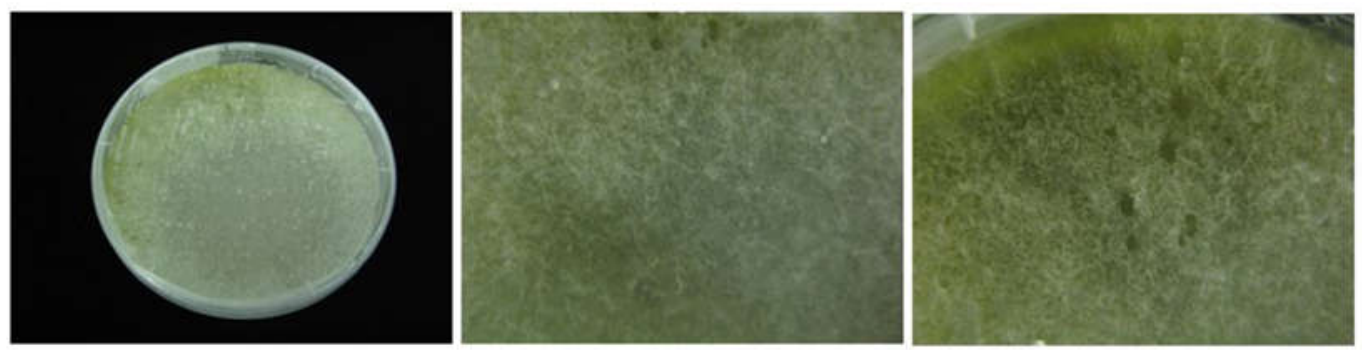

Gambar 14. Isolat kapang Trichoderma reesei pada medium Potatoes Dextrose Agar (PDA) (Sumber: Penulis, 2019)

Curvularia beasleyi

Koloni berwarna olivaceous black, memiliki hifa bersepta, conidiophore, conidiogenous cells, conidia berbentuk fusiform, dan berwarna cokelat hingga cokelat gelap. Tipe strain dari spesies ini ditemukan pada daun tanaman Kalamenta (Leersia hexandra) dan rumput Rhodes (Chloris gayana)
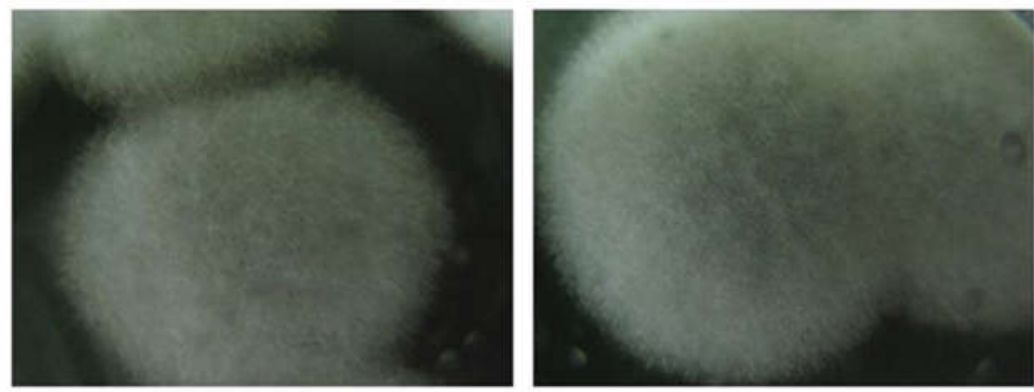

Gambar 15. Isolat kapang Curvularia beasleyi pada medium Potatoes Dextrose Agar (PDA) (Sumber: Penulis, 2019)

\section{Leang Bulu Sipong}

Jenis mikroorganisme yang telah diidentifikasi pada lukisan gua di Leang Bulu Sipong adalah bakteri Lysinibacillus fusiformis dan kapang Aspergillus brunneoviolaceus. Bakteri ini berbentuk batang, lebar sel $\leq 0,9 \mu \mathrm{m}$, bersifat aerob, Gram-variabel, membentuk spora. Suhu pertumbuhan $17-37^{\circ} \mathrm{C}$, tidak tumbuh pada suhu $5^{\circ} \mathrm{C}$ atau di atas $50^{\circ} \mathrm{C}$. 
Pertumbuhan pada $\mathrm{pH}$ 6,0 dan 9,5; dan pada 2-5\% NaCl. Type strain dari species ini diisolasi dari tanah.

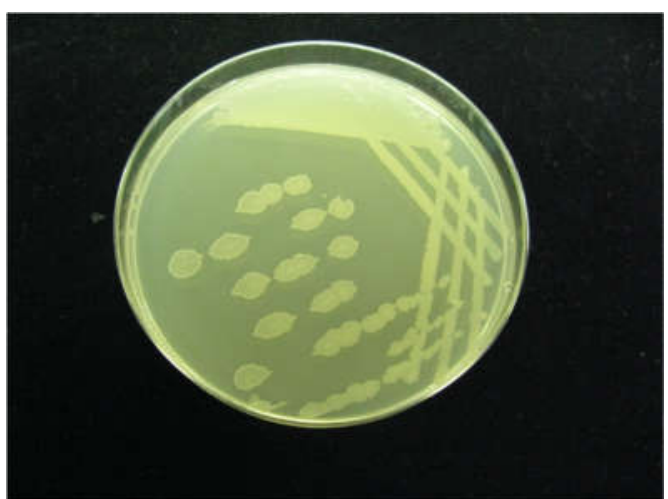

Gambar 16. Isolat bakteri Lysinibacillus fusiformis pada medium NA (Sumber: Penulis, 2019)

Kapang Aspergillus brunneoviolaceus termasuk ke dalam kelompok uniseriate black aspergilli. Koloni tumbuh pada suhu $35^{\circ}$ dan $37^{\circ} \mathrm{C}$ pada medium CYA. Koloni memiliki stipe, phialide, vesicle, conidia bulat hingga elips, berwarna cokelat hingga hampir hitam. Conidial head berwarna cokelat, cokelat gelap hingga hampir hitam, uniseriate.
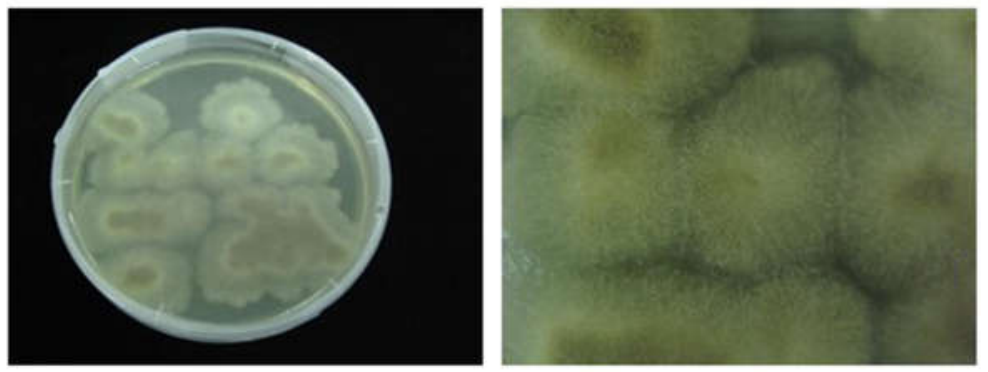

Gambar 17. Isolat kapang Aspergillus brunneoviolaceus pada medium Potatoes Dextrose Agar (PDA)

(Sumber: Penulis, 2019)

\section{LeangJarie}

Terdapat 4 jenis kapang yang telah berhasil diidentifikasi pada Leang Jarie. Keempat kapang tersebut terdiri dari Rhizopus oryzae, Aspergillus brunneoviolaceus, Aspergillus aflatoxiformans, dan Paecilomyces lilacinus. Rhizopus oryzae memiliki karakteristik, yaitu miselia berwarna putih, ketika dewasa miselia putih akan tertutup oleh sporangium yang berwarna abu-abu kecoklatan. Rhizopus oryzae tidak tumbuh pada $45^{\circ} \mathrm{C}$, tumbuh baik pada $40^{\circ} \mathrm{C}$. Kapang Rhizopus oryzae memproduksi enzim pendegradasi karbohidrat seperti amilase, selulase, xylanase, glukoamilase, dan sebagainya. 

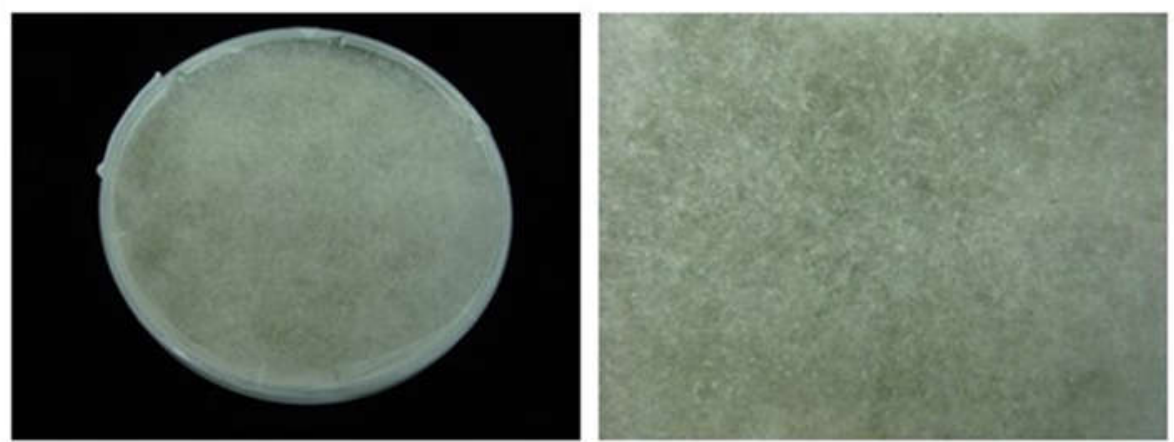

Gambar 18. Isolat kapang Rhizopus oryzae pada medium PDA (Sumber: Penulis, 2019)

Kapang Rhizopus oryzae biasa ditemukan dalam batuan gua, terutama batuan karst yang komposisi utamanya adalah $\mathrm{CaCO}_{3}$. Kapang ini mampu menguraikan kalsium karbonat yang berfungsi sebagai substrat lukisan cadas sebagai bahan dasar pembentukan asam laktat. Sehingga kapang ini juga dapat membahayakan lukisan cadas dengan cara menguraikan substrat gambar cadas.

Kapang Aspergillus aflatoxiformans memiliki ciri koloni menghasilkan konidia berwarna kuning-hijau. Koloni memiliki stipe, phialide, vesicle, conidia halus, subglobose. menghasilkan slerotia berwarna cokelat hingga hitam. Conidial head berwarna kuning-hijau, berbentuk radiate atau columnar, uniseriate.
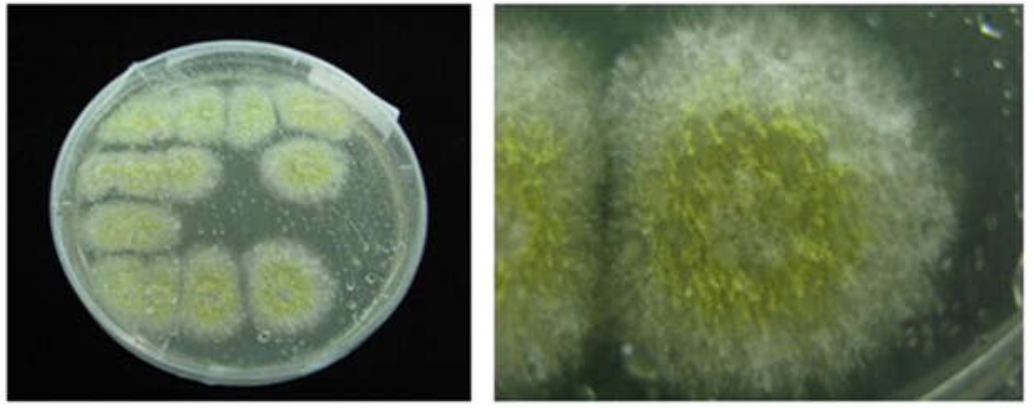

Gambar 19. Isolat kapang Aspergillus aflatoxiformans pada medium PDA (Sumber: Penulis, 2019)

Paecilomyces lilacinus membentuk floccose colony. Koloni memiliki conidiophore, verticillate branches, phialides, conidia berbentuk ellipsoidal, atau fusiform, halus atau agak kasar.

\section{Pembahasan}

Potensi pelapukan dan deteriorasi lukisan cadas menjadi semakin cepat dengan adanya bakteri dan jamur. Mikroorganisme tersebut berpengaruh baik secara langsung maupun tidak langsung terhadap proses deteriorasi gambar cadas. Bakteri dari famili Bacillacea mampu berkompetisi sangat baik dengan mikroorganisme yang lain dengan membentuk spora yang resisten dan memproduksi senyawa metabolit yang bersifat antagonistik bagi mikroorganisme lainnya. Metabolit yang dihasilkan juga dapat merubah bentuk pigmen lukisan dinding gua dan electron valensi dari elemen pigmen. Proses tersebut terjadi ketika diskolorisasi (perubahan warna) pigmen lukisan dinding gua. Kelompok bakteri Bacillaceae mampu mereduksi Fe(III), seperti hematite dan goethite (Gonzalez et al., 1999). Kemampuan tersebut membuktikan bahwa bakteri Bacillaceae 
mampu menggunakan pigmen berbahan dasar besi $(\mathrm{Fe})$ dari gambar cadas. Pada kondisi tertentu (keterediaan bahan organic dan air), bakteri dapat merubah warna lukisan dinding gua dari merah menjadi kecoklatan. Mengindikasikan adanya senyawa besi (ferrous).

Bakteri Lysinibacillus fusiformis mempunyai kemampuan untuk membentuk endapan (presipitasi) pada batuan karst. Endapan karbonat dapat menutupi gambar cadas apabila proses presipitasi tepat terjadi lokasi gambar cadas. Mekanisme presipitasi bakteri Lysinibacillus fusiformis dapat dilakukan dengan cara pasif dan aktif. Cara aktif disebabkan oleh aktivitas metabolism bakteri Lysinibacillus fusiformis. Aktivitas metabolism tersebut dapat meningkatkan $\mathrm{pH}$ disekitar lingkungan bakteri Lysinibacillus fusiformis, akibatnya adalah terbentuknya ion karbonat $\left(\mathrm{CO}_{3}{ }^{2}\right)$, dan ion karbonat tersebut dapat mengendap menjadi kalsium karbonat $\left(\mathrm{CaCO}_{3}\right)$ jika bertemu dengan ion kalsium $\left(\mathrm{Ca}^{2+}\right)$. Mekanisme aktif dilakukan oleh bakteri Lysinibacillus fusiformis ketika pemasukan dan pengeluaran ion kalsium melalui saluran protein (protein channels), saluran non proteins, dan pompa ATP (Adenosine Triphosphate). Ion $\mathrm{Ca}^{2+}$ dikeluarkan dari dalam sel bakteri jika terdapat $\mathrm{CO}_{3}{ }^{2}$.

Kerusakan gambar cadas yang disebabkan oleh kapang dapat diklasifikasikan menjadi dua, yaitu kerusakan fisik dan kimia. Kerusakan fisik diakibatkan oleh pertumbuhan hifa tubuh buah (fruiting bodies) di atas dan di bawah lapisan permukaan gambar cadas. Penetrasi hifa ke dalam pigmen dapat mencabut beberapa lapisan pigmen (Wazny \& Rudniewsky,1972).
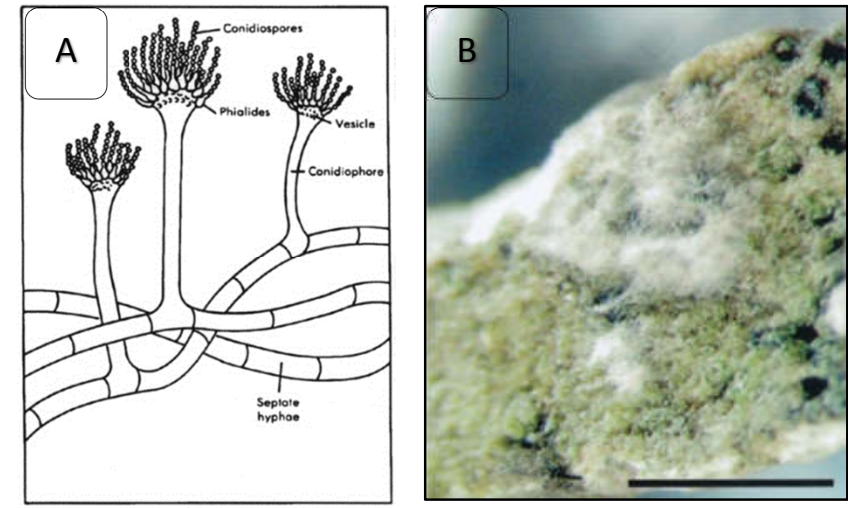

Gambar 20. Kapang (A) Struktur kapang (B) hifa yang menutupi permukaan batu (C) tubuh buah (Sumber: Burford, E. P., et al., 2003)

Kerusakan secara kimiawi disebabkan karena metabolit yang dihasilkan oleh jamur. Beberapa aktivitas jamur yang dapat merusak lukisan dinding gua adalah:

a. Produksi asam (Acid production)

Ketika proses metabolisme, jamur mengeluarkan asam seperti gluconic, citric, oxalic, malic, succinic, itaconic, dan lain sebagainya. Asam tersebut bereaksi dengan beberapa bahan dalam pigmen dengan cara melarutkan kation atau ion logam pigmen. Asam dari fungi juga menghasilkan penggaraman, sebagai contoh asam oksalat bereaksi dengan ion kalsium membentuk whewellite dan weddellite.

b. Produksi Enzim

Enzim ekstraseluler yang dihasilkan fungi dapat merubah senyawa kompleks (protein, selulosa, hemiselulosa, lignin) ke dalam bentuk sederhana. Aktivitas enzimatik dapat melonggarkan, cracking, melepaskan lapisan pigmen. Selain itu, juga dapat merusak binder lapisan pigmen (Rebricova, 1993). Enzim ekstraseluler juga memudahkan penetrasi hifa ke dalam lapisan pigmen.

c. Pembentukan Pigmen 
Sebagai konsekuensi aktivitas metabolism, fungi memproduksi pigmen yang berbeda-beda (hijau, abu-abu, biru, ungu, dll). Pigmen yang dihasilkan fungi menyebabkan perubahan tampilan warna lukisan dinding gua.

\section{KESIMPULAN}

Berdasarkan hasil identifikasi jenis, ditemukan beberapa bakteri dan jamur di antaranya adalah Bacillus toyonensis, B. thuringiensis, Brevibacillus brevis, Lysinibacillus fusiformis, dari kelompok bakteri dan Penicillium citrinum, Aspergillus fumigatus, Aspergillus brunneoviolaceus, Trichoderma reesei, Rhizopus oryzae, Curvularia beasleyi, Aspergillus aflatoxiformans, Paecilomyces lilacinus dari kelompok kapang. 


\section{DAFTAR PUSTAKA}

Aubert, M., A. Brumm, M. Ramli, T. Sutikna, E.W. Saptomo, B. Hakim, M.J. Morwood, G.D. van den Bergh, L. Kinsley, dan A. Dosseto. "Pleistocene cave art from Sulawesi, Indonesia.” Nature 514, (2014): 170-223.

Aubert, M., R. Lebe, A.G. Oktaviana, M. Tang, B. Burhan, Hamrullah, A. Jusdi, Abdullah, B. Hakim, Zhao Jian-xin, I.M. Geria, P.H. Sulistiyarto, R. Sardi, dan A. Brumm "Earliest Hunting Scene in Prtehistoric Art." Nature 576, (2019): 1-4

Bednarik, Robert. Rock Art Conservation. Australia: International Federation RockArt Organization, 2003.

Bray, Wawick dan David Trump. A Dictionary of Archaeology. Allen Lane: ThePenguin Press, 1970.

Burford, E. P., Kierans, M., Gadd, G. M. "Geomycology: Fungi in Mineral Subtrata." Mycologist 17, (2003): 98-107

Gonzalez, I., L. Laiz, B. Hermosin, B. Caballero, C. Incerti, dan C. Saiz-Jimenez. "Bacteria isolated from rock art painting: the case of Atlanterra shelter (South Spain).” Journal of Microbiological Methods 36, (1999): 123-127

Mulyadi, Yadi. "Kajian Keterawatan Lukisan Gua Prasejarah di Kawasan Karst MarosPangkep Sulawesi Selatan.” Jurnal Konservasi Cagar Budaya BOROBUDUR 10, No. 1 (2016): 15-27.

Permana, R. Cecep Eka. Pola Gambar Tangan Pada Gua-Gua Prasejarah di Wilayah Pangkep-Maros Sulawesi Selatan. Disertasi Universitas Indonesia, 2008.

Permana, R. Cecep Eka. "Rock art in South Sulawesi (Indonesia) and their Conservation issues." Makalah dalam the 23th Conference on International Cooperation in Conservation 2009. Tokyo: National Research Institute for Cultural Properties, 8 Oktober 2009.

Permana, R. Cecep Eka. Gambar Tangan Gua-Gua Prasejarah Pangkep-MarosSulawesi Selatan. Jakarta: Wedatama Widya Sastra, 2014.

Permana, R. Cecep Eka. "Lukisan Dinding Gua (Rock Art): Keterancaman dan Upaya Konservasinya", dalam.Jurnal Konservasi Cagar Budaya BOROBUDUR 9, No. 2 (2015): 43-51.

Permana, R. Cecep Eka (ed). Gambar Cadas prasejarah di Indonesia. Jakarta: Direktorat Pelestarian Cagar Budaya dan Permuseuman, 2015.

Permana, C.E., A. Oetari, M. Habibi, dan E. Gunawan. Preservasi dan Konservasi Gambar Cadas Indonesia: Studi Kasus Gua Prasejarah di Kawasan Karst Maros-Pangkep Sulawesi Selatan. Penelitian Terapan Unggulan Perguruan Tinggi DIKTI-UI tahun 2019

Rebricova, N.L. "Micromycetes taking part in deterioration of old Russian wall paintings." Recent Advances in Biodeterioration and Biodegradation 1, (1993): 205-32.

Samidi. Laporan Hasil Survey Konservasi Lukisan Gua Sumpang Bita dan Pelaksanaan Konservasi Lukisan Gua Pattae Kere. Proyek Pemugaran dan Pemeliharaan Peninggalan Sejarah dan Purbakala Sulawesi Selatan, 1985.

Samidi. Laporan Konservasi Lukisan Perahu/Sampan di Gua Sumpang Bita (Tahap awal) dan Konservasi Lukisan Babi Rusa di Gua Pattae Kere (Penyelesaian). Proyek Pemugaran dan Pemeliharaan Peninggalan Sejarah dan Purbakala Sulawesi Selatan, 1986.

Soejono, R.P. dan R.Z. Leirissa RZ. Sejarah Nasional Indonesia I (edisi Mutakhir). Jakarta: PN Balai Pustaka, 2009.

Suhartono, Yudi, Yudi Atmaja, dan Riyanto P Lambang. Studi Konservasi LukisanGua Prasejarah di Maros dan Pangkep. Magelang: Balai konservasi Peninggalan Borobudur, 2008. 
Suhartono, Yudi. Faktor-faktor Penyebab Kerusakan Lukisan Gua Prasejarah diMaros Pangkep dan Upaya Penanganannya. ”Jurnal Konservasi Cagar Budaya BOROBUDUR 6, No. 6 (2012): 14-25.

Sukamto, R."The structure of Sulawesi in the light of plate tectonics." Dalam Proceedings of the Regional Conference on the Geology and Mineral Resources of SE Asia, 125. Jakarta, 1975.

Sukamto, R. Geologi lembar Pangkajene dan Watampone bagian barat, Sulawesi Selatan. Bandung: Geological Research and Development Centre, 1982.

Susanti, Dewi. "Strategi Konservasi Berbasis Masyarakat pada Kompleks Situs Gua Prasejarah Bellae, Kabupaten Pangkep, Provinsi Sulawesi Selatan.” Jurnal Konservasi Cagar Budaya BOROBUDUR 10, No. 1 (2016): 3-14.

Taçon, Paul S.C. dan Christopher Chippindale. "Introduction: An Archaeology of Rockart Through Informed methods and formal methods."Dalam Christopher Chippindale dan Paul S.C. Taçon (ed.), The Archaeology of Rock Art, 1-10. Cambridge: Cambridge University Press, 1998.

Tim Pelaksana. Laporan Zonasi Gua-Gua Prasejarah Kabupaten Maros. Makassar: Balai Pelestarian Cagar Budaya Makassar, 2011.

Tim Pelaksana. Laporan Delineasi Kawasan Gua Prasejarah Maros-Pangkep. Makassar: Balai Pelestarian Cagar Budava Makassar, 2011.

Van Leeuwen, T.M. "The geology of southwest Sulawesi with special reference to The Biru area." Dalam A.J. Barber \& S. Wiryosujono (eds), The Geology and Tectonics of Eastern Indonesia, 277-304. Bandung: Geological Research and Development Centre, Special Publication, 2, 1981.

Wazny, J. dan P. Rudniewski. "Microbial biodeterioration on Rock paintings.” Material and Organism 7, (1972): 81-92.

Wilson, M.E.J., dan D.W.J. Bosence. "The Tertiary evolution of South Sulawesi: a record in redeposited carbonates of the Tonasa Limestone Formation.” Geological Society Special Publication No. 106 (1996): 365-89.

Yuwono, Y.S., H. Bellon, P. Soeria-Atmadja dan R.C. Maury. "Neogene and Pleistocene volcanism in South Sulawesi." Proceedings Ikatan Ahli Geologi Indonesia 14, (1985): 169-79. 